This is not a peer-reviewed article.

Pp. 034-043 in the Ninth International Animal, Agricultural and Food Processing Wastes Proceedings of the 12-15 October 2003 Symposium (Research Triangle Park, North Carolina USA), Publication Date 12 October 2003.

ASAE Publication Number 701P1203, ed. Robert T. Burns.

\title{
USE OF Composted Waste MATERIAls In ERosion ConTrol
}

\author{
L. M. Risse and L. B. Faucette
}

\begin{abstract}
The objective of this series of studies was to investigate the use of compost and mulch materials in erosion control and stabilization projects. The first phase of the study primarily looked at the impacts of surface blankets of twelve different compost and mulch materials on total solids (TS) loss and water quality and found that mulch blankets produced runoff with the lowest TS and nutrient contents. Compost blankets were significantly less erodible than bare soil. Compost maturity seemed to be an important factor as respiration rate was significantly correlated to TS loss. Raw poultry litter produced more runoff and erosion than bare soil and three different poultry litter composts. Effective erosion control strategies must both protect the soil surface and establish and sustain vegetation. The second part of this project looked at the impacts of these same materials on grass establishment and growth. The findings indicated that the compost treatments produced more vegetative biomass and cover than the mulch treatments. The final phase of this study compared four combinations of compost blankets and berms to both bare soil and conventional treatments such as hydroseeding and silt fences. Preliminary results indicate that the use of compost blankets and berms offer significant improvements in water quality through improved erosion control, reduction in nutrient loads, and improved the establishment of vegetation. Further analysis is on-going to document the long term changes in soil quality and vegetation using these treatments.
\end{abstract}

KEYWORDS. Compost, Animal waste, Soil Erosion, Runoff, Manure

\section{INTRODUCTION}

Sediment has been identified as one of the most important nonpoint source pollutants of streams, lakes, and estuaries. Sediment is recognized as a pollutant that impacts aquatic organisms, habitat, and is also a carrier of other nonpoint source pollutants (Ermine and Ligon, 1988). While sources of sediment and other non-point source pollutants include agriculture and forestry, other land uses such as construction, development, and roads are being recognized as the major contributors in urban and developing areas. In fact, soil loss rates from construction sites are typically 10-20 times those from agricultural land (USEPA, 1997). New EPA regulations label stormwater discharges from construction sites as "point sources" requiring improved erosion control practices and new permitting programs. In addition, road construction and maintenance are commonly recognized as significant sources of sediment requiring substantial investment in erosion control and vegetation establishment.

Currently, common erosion control practices for construction projects and road development in Georgia consists of silt fences, hydroseeding, and establishing vegetation. Several demonstration projects have suggested that the use of compost and mulch applications could improve upon existing erosion control technologies (Demars et al., 2000, Glanville et al., 2001, Michaud, 1995, and Mitchell, 1997). The use of compost and mulches in erosion control has additional benefits of being a more sustainable method of dealing with "waste" materials. With agricultural byproducts such as animal manure, compost production also represents a method of improving the nutrient balance on the farm through the development of off-farm uses. Utilization of other 
organic byproducts such as municipal biosolids, wood waste, food processing residuals, and municipal solid waste could also be improved through composting if value added markets were available. Many of these organic by-products are generated near urban and developing areas where the need for erosion control technologies is often greatest.

\section{OBJECTIVES}

The overall goal of this series of studies is to develop a better understanding of the characteristics of composts and mulches related to their use in erosion control technologies and to demonstrate the effectiveness of these materials. This paper reports on the results of three separate studies. The objective of the first study was to measure the erodibility of various compost and mulch materials under simulated rainfall and relate the measured erodibility to the physical and chemical properties of the materials. The objective of the second study was to look at these same materials and measure the impact on vegetation establishment. The final study used results from the earlier studies to select and establish field plots for compost and mulch materials that showed the most potential to control soil erosion and compare these treatments to standard construction practices.

\section{LITERATURE REVIEW}

Conventional methods to control moving sediment include silt fencing and riprap; while hydro seeding, wood fiber mats, coconut hull fiber mats and straw mats are conventional means to prevent soil erosion from occurring. Surface applied organic mulches to protect the soil surface can significantly reduce both runoff and soil erosion (Adams, 1966; Meyer et al., 1972; Laflen et al., 1978; Vleeschauwer et al., 1978; Foster et al., 1985; Agassi et al., 1998). The mechanisms behind these reductions include less soil crust formation in the underlying soil, dissipation of the energy associated with raindrop impact, and a reduction in the shear forces exerted on the soil surface. Surface layers of organic matter reduce the energy of raindrop impact and allow water to percolate into the soil reducing surface runoff and erosion. The rougher surface created by mulches and some composts also allows for greater water storage and percolation and lower runoff velocities (Kramer and Meyer, 1969). Composted wood waste has also been shown to increase water infiltration and water holding capacity by improving soil structure (Demars et al., 2000). Applications of animal manure to soil surfaces can also reduce runoff and soil erosion, however; the mechanisms behind these reductions are not well defined (Gilley and Risse, 2001; Giddens and Barnett, 1980). In addition, a layer of organic litter on the soil surface insulates the soil and reduces evaporation creating a better environment for germination and root growth and therefore improved vegetative cover. Establishment of vegetative cover can then provide for long term protection of the soil surface.

Current literature suggests that many states have experimented with using compost to control soil erosion informally, but there is little scientific literature on the impacts of compost blankets on erosion or water quality. A survey by Mitchell (1997) indicated that 19 state's Department of Transportation had developed specifications for compost use and at least six had conducted experiments on using compost to control soil erosion. Michaud (1995) suggests that blanket applications of up to $10 \mathrm{~cm}$ of compost will effectively control erosion on slopes up to $45 \%$ for up to 3 years. Demars et al., (2000) showed that blankets of both yard waste mulch and yard waste compost reduced erosion by an order of magnitude and that the compost treatments performed as well or better than the conventional treatment of hay and seed. Storey et al. (1996) compared compost amended plots and plots mulched with shredded wood to synthetic chemical tackifiers and found that compost amended plots reduced erosion as well or better than the other treatments with the greatest reductions on sandy soils. Glanville et al. (2001) compared three types of compost to bare soil and traditionally treated soils on new high embankments in Iowa. They found that runoff from all three compost plots were significantly lower than the control and runoff from bio-industrial and yard waste compost were significantly lower than plots amended with topsoil. 
Although erodibility is defined as a soil property and is quantified in terms of total solids loss, composts and mulches should display a similar property relative to the total solids lost from a surface cover. Very few people have investigated the measurement of erodibility on composts or mulches, but if we assume that total solids includes both soil and eroded compost or mulch materials, then the erodibility of these materials should be directly related to the total solids lost when these materials are subjected to erosive forces. Westerman et al. (1983) studied the erodibility of layer manure and broiler litter on sand and clay soils. They found that the addition of manure or litter resulted in increased transport of solids and nutrients in the runoff, yet the erodibility of the manure was greater than the erodibility of sand but less than that for clay. Many of the previously mentioned studies have attempted to quantify the total solids lost from compost or mulch blankets but few have related this data to the characteristics of the cover material. The erodibility of composts or mulches should be an important factor in its ability to control erosion yet little is known about the erodibility of these materials.

\section{Part 1: Interill Pan Studies}

\section{Materials and Methods}

Eleven treatments including three poultry litter composts, a municipal solid waste compost, a food waste compost, a yard waste compost, a municipal sludge/peanut hull compost, three grades of wood mulches and a bare soil control were selected for use in this study (Table 1). These treatments were selected based on their availability commercially and previous studies of feedstock quantities produced in Georgia. Each of the materials was supplied by a commercial vendor and was tested as supplied. The bare soil control (eroded Cecil sandy clay loam) was obtained from a construction site that had undergone extensive grading and soil relocation. Initial plans called for three replicates of each treatment; however, due to limited supplies fewer replicates were used on many of the plots (Table 1).

Table 1 Treatment Names and Descriptions

\begin{tabular}{ccc}
\hline $\begin{array}{c}\text { Treatment } \\
\text { Name }\end{array}$ & Description/Primary Feedstocks & Replicates \\
\hline PLC1 & Poultry gold compost/Poultry litter & 2 \\
PLC2 & Sargents nutrients compost/Poultry litter & 2 \\
PLC3 & Gro-mor compost/Poultry litter, vegetable waste, yard waste & 1 \\
PL & Aged poultry litter/ Layer manure from underhouse storage & 2 \\
MSC & Cobb Co. compost/ Municipal solid waste and sludge & 2 \\
BSC & Erthfood compost/Municipal sludge, peanuts hulls & 3 \\
FWC & Creative earth compost/Food residuals, ground wood waste & 2 \\
YWC & UGA compost/Yard waste, ground wood waste, some manure & 3 \\
WMf & Woodtech superfine mulch/Finely ground wood mulch & 2 \\
WMm & Woodtech medium hardwood mulch/Medium ground wood mulch & 3 \\
WM2 & Rockdale Co. mulch/Course ground yard waste and waste wood & 2 \\
Soil & Bare soil control & 3 \\
\hline
\end{tabular}

The physical and chemical properties of each treatment and methods of measurement are reported in Risse et al., (2002). Bulk density, moisture content, total and volatile solids, major nutrients, aggregate and particle size, $\mathrm{pH}, \mathrm{C}: \mathrm{N}$ ratio, soluble salts, and respiration rate were measured for each material. Metals were analyzed and all of the treatments were below the pollutant levels as specified in USEPA Part 503 Table 3.

Each replicate was placed in a $92 \mathrm{~cm}$ by $107 \mathrm{~cm}$ stainless steel frame that was $15 \mathrm{~cm}$ deep. These frames were attached to a plywood base that was placed at a $10 \%$ slope and equipped with a flume on the downslope end. The bottom of the flume was $5 \mathrm{~cm}$ below the lip of the frame giving each collector an effective depth of $10 \mathrm{~cm}$ with a $5 \mathrm{~cm}$ border above the soil surface. Three $2.5 \mathrm{~cm}$ holes were drilled in the plywood base to allow for seepage, however, little seepage occurred during the testing period. Five centimeters of soil was placed in the bottom of each collector and covered with cheese cloth and an additional $5 \mathrm{~cm}$ of compost or mulch material for 
each run (except for the bare soil treatment). Between each run, the compost or mulch material would be removed, the collector and soil surface would be rinsed and repacked if necessary, and the next treatment would be loaded into the collector. While the surface would be smoothed to insure that it was flush with the flume edge and at a constant slope, no attempts were made to pack the compost, mulch, or soil treatments to an equal density. Prior to the initial run and to loading the treatments, the subsoil was pre-wet with approximately to insure uniform initial conditions.

An eight nozzle (V-jet nozzle operating at 60 psi) Norton rainfall simulator obtained from the National Soil Erosion Research Laboratory was used for this study. The simulator uniformly approximately covered a $6 \mathrm{~m}$ by $2 \mathrm{~m}$ area with rainfall. Therefore, four collectors fit under the simulator for each rainfall event. Actual rainfall rates were measured using 10 gages for each run. Average measured rainfall rates were $16 \pm 0.7 \mathrm{~cm} / \mathrm{hr}$ and each run lasted for one hour. As soon as runoff began, which ranged from 3 (soil) to 23 (mulch) minutes after rainfall was started, an initial sample of approximately $500 \mathrm{ml}$ of runoff was collected. Additional samples were then collected at five minute intervals until a total elapsed time of 60 minutes had been reached. The weight of runoff and time over which it was collected was recorded at five minute intervals. From this data, the runoff rate at five minute intervals during the simulation was plotted and the total runoff amount was calculated by summing the area under the runoff curve. In addition, each sample bottle was oven dried at $105^{\circ} \mathrm{C}$ until constant weight was achieved to determine the total solids content and total amount of solids lost from the plot. Volatile solids (VS), total solids (TS), total phosphorus (TP), Ortho-phosphorus $\left(\mathrm{PO}_{4}\right)$, total nitrogen $(\mathrm{TN})$, nitrate nitrogen $\left(\mathrm{NO}_{3}\right.$ $\mathrm{N})$, and ammonia nitrogen $\left(\mathrm{NH}_{4}-\mathrm{N}\right)$ were analyzed for the first sample and at the end of the run (steady state sample). Total nutrient loads were estimated by averaging the concentrations of the first flush and steady state and multiplying by the runoff volume. SAS version 8.0 (SAS, 1999) was used for the statistical analysis which include an analysis of variance (PROC ANOVA) using Duncan's Multiple Range test for significant differences with unequal cell sizes and correlation analysis (PROC CORR). These procedures were used to determine which of the physical and chemical treatment parameters were correlated to the measured runoff and solids loss.

\section{Pan Study Results}

There was significant variability in the runoff volume and the total solids loss between the treatments (Table 2). The poultry litter treatment had highest runoff volume and steady state rate (not shown) and was significantly higher than the plots with mulch cover. This was probably due to the fact that the litter appeared to be somewhat hydrophobic. At the end of the rainfall simulation, it was noted that the wetting front had not advanced through the layer of poultry litter. None of the other treatments exhibited this and most appeared totally saturated. Although not significantly different, the composted poultry litters had less runoff and behaved more like the other treatments. The composting process appeared to reduce the hydrophobic properties of the poultry litter. The fine and medium mulches had the lowest runoff rates and volumes. The mulches had the most storage volume (pore space) and took the longest to generate runoff due to the higher infiltration rate. There were very few differences in runoff among the compost treatments. Near the end of the simulation, when most of the cover treatment was saturated, all of the treatments with the exception of the poultry litter and mulches had similar runoff rates and there were no significant differences. The runoff rates only varied from 17 to $26 \mathrm{ml} / \mathrm{s}$ and this could probably be attributed to differences in the rainfall rates and plot preparation. Under field conditions where the treatments are given time to influence vegetation and soil properties or with lower rainfall rates, greater differences in runoff rates and volumes would be expected.

The solids loss data exhibited more differences between treatments (Table 2 and Figure 1). Total solids loss for the poultry litter treatment was significantly higher than any other treatment. Total

Table 2 Runoff, Solids and Nutrient Loss Data

\begin{tabular}{cccccccc}
\hline Treatment & Runoff Volume & Solids & $\mathrm{TN} \mathrm{Load}$ & $\mathrm{NO}_{3}-\mathrm{N}$ Load & $\mathrm{NH}_{4}-\mathrm{N}$ Load & $\mathrm{TP} \mathrm{Load}$ & $\begin{array}{c}\mathrm{PO}_{4} \mathrm{Load} \\
(\mathrm{mg})\end{array}$ \\
& $(\mathrm{L})$ & loss $(\mathrm{g})$ & $(\mathrm{mg})$ & $(\mathrm{mg})$ & $(\mathrm{mg})$ & $(\mathrm{mg})$ & $(\mathrm{mg})$ \\
\hline
\end{tabular}




\begin{tabular}{cccccccc}
\hline PLC1 & $74 \mathrm{ab}$ & $552 \mathrm{bc}$ & $4128 \mathrm{~b}$ & $2343 \mathrm{bc}$ & $138 \mathrm{~b}$ & $10046 \mathrm{~b}$ & $7588 \mathrm{~b}$ \\
PLC2 & $44 \mathrm{bc}$ & $208 \mathrm{~cd}$ & $1272 \mathrm{c}$ & $751 \mathrm{~cd}$ & $45 \mathrm{~b}$ & $1589 \mathrm{~b}$ & $1253 \mathrm{~b}$ \\
PLC3 & $52 \mathrm{abc}$ & $168 \mathrm{~cd}$ & $4679 \mathrm{~b}$ & $3125 \mathrm{~b}$ & $101 \mathrm{~b}$ & $1085 \mathrm{~b}$ & $903 \mathrm{~b}$ \\
PL & $83 \mathrm{a}$ & $1221 \mathrm{a}$ & $1327 \mathrm{c}$ & $14 \mathrm{~d}$ & $6573 \mathrm{a}$ & $30266 \mathrm{a}$ & $23755 \mathrm{a}$ \\
MSC & $47 \mathrm{bc}$ & $236 \mathrm{~cd}$ & $645 \mathrm{c}$ & $410 \mathrm{~d}$ & $194 \mathrm{~b}$ & $294 \mathrm{~b}$ & $242 \mathrm{~b}$ \\
BSC & $53 \mathrm{abc}$ & $154 \mathrm{~cd}$ & $8113 \mathrm{a}$ & $6301 \mathrm{a}$ & $241 \mathrm{~b}$ & $2693 \mathrm{~b}$ & $2217 \mathrm{~b}$ \\
FWC & $37 \mathrm{bc}$ & $139 \mathrm{~cd}$ & $628 \mathrm{c}$ & $840 \mathrm{~cd}$ & $33 \mathrm{~b}$ & $219 \mathrm{~b}$ & $213 \mathrm{~b}$ \\
YWC & $63 \mathrm{abc}$ & $111 \mathrm{~cd}$ & $744 \mathrm{c}$ & $321 \mathrm{~d}$ & $57 \mathrm{~b}$ & $199 \mathrm{~b}$ & $170 \mathrm{~b}$ \\
WMf & $35 \mathrm{c}$ & $102 \mathrm{~d}$ & $64 \mathrm{c}$ & $6 \mathrm{~d}$ & $15 \mathrm{~b}$ & $28 \mathrm{~b}$ & $23 \mathrm{~b}$ \\
WMm & $48 \mathrm{bc}$ & $144 \mathrm{~cd}$ & $97 \mathrm{c}$ & $20 \mathrm{~d}$ & $7 \mathrm{~b}$ & $32 \mathrm{~b}$ & $16 \mathrm{~b}$ \\
WM2 & $66 \mathrm{abc}$ & $74 \mathrm{~d}$ & $434 \mathrm{c}$ & $32 \mathrm{~d}$ & $94 \mathrm{~b}$ & $357 \mathrm{~b}$ & $304 \mathrm{~b}$ \\
Soil & $71 \mathrm{ab}$ & $646 \mathrm{~b}$ & $150 \mathrm{c}$ & $42 \mathrm{~d}$ & $20 \mathrm{~b}$ & $52 \mathrm{~b}$ & $57 \mathrm{~b}$ \\
\hline
\end{tabular}

* Treatments with the same letter are not significantly different at Alpha $=0.05$.

solids loss on the bare soil was significantly higher than all but one other treatment. Generally the mulch treatments had the lowest total solids loss although these were not statistically different than many of the compost treatments. During the simulation, the poultry litter treatment and the bare soil control were the only treatments that displayed rill formation where the flow concentrates and forms small rills indicating erosion by flow stresses rather than just raindrop impact and sheetflow. By protecting the soil surface, all of the treatments, except the poultry litter, seemed to reduce or eliminate the impacts of concentrated flow and rill erosion. Some floating solids were visible in the runoff samples especially from the fine mulch and poultry litter treatments; however, this was not a large portion of the solids loss. Initially, there was some concern that the mulch treatments might float resulting in higher solids loss, but this did not occur.

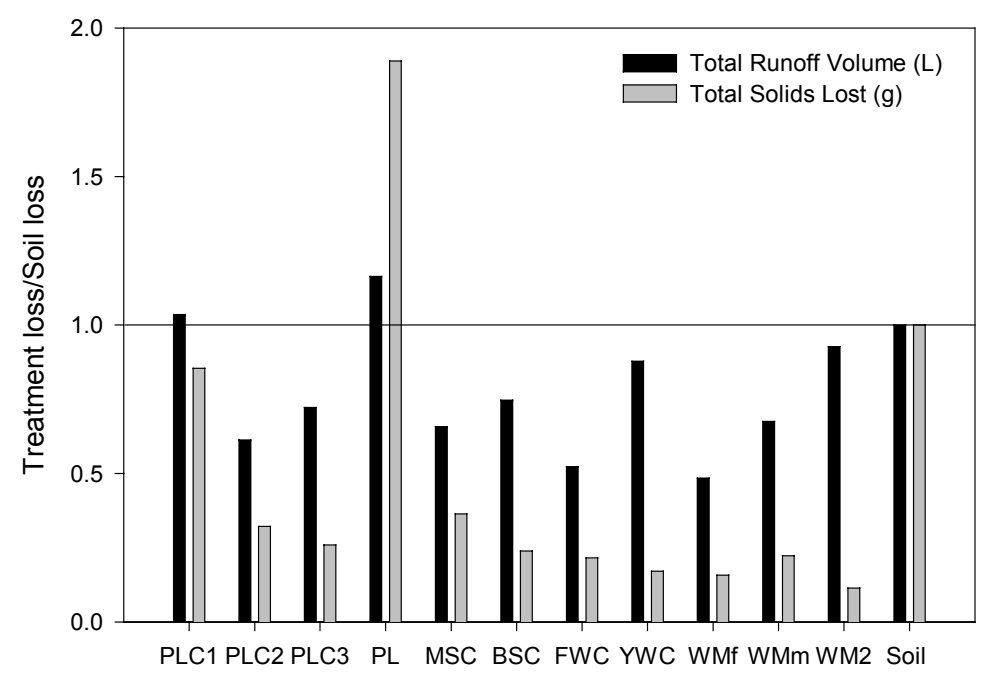

Figure 1 Runoff and Soil Loss Relative to Soil.

The biosolids compost had significantly higher total nitrogen and nitrate losses than any other treatments, even though the poultry litter had higher total nitrogen and nitrate contents in the initial analysis of the composts. This may indicate that this nitrogen in the municipal sludge was more water soluble. The poultry litter had significantly higher ammonia losses than any other treatment even though many other treatments had higher ammonia contents in the initial analysis. This indicates that the nutrients in some of the compost treatments were more available to runoff than equivalent concentrations in other treatments. The mulch and soil treatments generally had lower total nitrogen, nitrate, and ammonia losses, however, these were often not statistically significant. The phosphorus losses were significantly higher for the poultry litter treatment. Even though this was the only statistically significant difference, many of the compost treatments had P losses one or two orders of magnitude greater than the soil or mulch treatments. All of the 
nutrient loss concentrations were surprisingly high compared to values reported in field studies and to EPA standards for human or aquatic health. The high nutrient levels may be due to the fact that this simulation was conducted under worse case conditions including first flush following application with little opportunity for available nutrients to move into the soil, no vegetation, and very intense prolonged rainfall.

The results from correlation analysis were used to investigate which of the physical and chemical parameters of the treatment material were correlated with each of the output parameters measured in the runoff. All of the measured physical and chemical characteristics were tested against all measured runoff, solids loss, and nutrient loads. None of the independent variables measured were well correlated with total runoff volumes or rates. Total solids loss was correlated to the respiration rate and the nitrate-nitrogen content of the treatment. Treatments with lower respiration rates and nitrate concentrations tended to show a reduction in the loss of solids. The soil and poultry litter had the highest respiration rates (respiration rate is measured per gram of volatile solids and the soil had the lowest amount of volatile solids) and the highest amounts of solid loss. Likewise, nitrate-nitrogen content, respiration rates, soluble salt, sodium, and potassium contents were good indicators of ammonium and phosphorus losses. Soil erosion studies have indicated that particle size has a significant impact on erodibility; however, the aggregate size analysis in this study was not well correlated to the erosion observed. This may be due to the fact that only the large classifications were measured in this study. Further analysis should investigate smaller particle size classifications and include them in the correlation analysis.

\section{Part 2 Vegetation Establishment}

While study one indicates that all of the treatments with the exception of poultry litter can be effectively used to reduce soil erosion and solids loss, for the most part the wood mulch treatments were more effective and offered the added benefit of reduced nutrient losses. However, the goal of a soil cover should be to provide for short term protection with little environmental impact while vegetation is being established. Ultimately, the vegetation establishment is an equally important goal and the nutrients in the compost treatments should aid in this process. Part two of this study was designed to look at vegetation establishment for each of the treatments. Ultimately, the results from both studies should be combined to develop decision aids in the selection of compost and mulch materials for erosion control.

\section{Materials and Methods}

Twelve treatments from Part 1 were used in this study. Minor modifications to the treatments included substituting a mixture of poultry litter compost and mulch for the poultry litter and using a hydro-seeded control instead of bare soil. The experiment was conducted in 18.9 L (5 gal) pots. Each treatment contained six replicates. The bottom of the pots contained an eroded Cecil clay loam soil taken from a construction site. The soil was covered with $3.81 \mathrm{~cm}$ (1.5 inch) of organic media or mixture of medium. Perennial ryegrass seeds were broadcast by hand at a rate of $4.88 \mathrm{~kg}$ per $100 \mathrm{sq} \mathrm{m}(10 \mathrm{lbs}$ per $1,000 \mathrm{sq} \mathrm{ft})$ and covered with $1.27 \mathrm{~cm}(1 / 2 \mathrm{inch})$ blanket of the corresponding media. The hydro-seeded treatments were established by taking the pots to a commercial site where the hydro-seed mixture was applied on the top the soil by the Georgia Department of Transportation. The hydro-seed solution contained water, wood mulch, 10-10-10 NPK granulated fertilizer, and a mixture of ryegrass and Bermuda grass seed. While attempts were made to assure uniform application, actual rates were not measured and the seeding rates on these pots were not the same as the other treatments.

The pots were seeded in November and irrigated $(1.25 \mathrm{~cm}$ per application) twice a week in the first two weeks. Percent cover and vegetative dry mass were determined on three replicates after two and six months. By dividing the pot area into 18 line transects with points every $2 \mathrm{~cm}$, the percent cover was determined by dividing the points where vegetation was present by the total number of points. The biomass weight was determined by clipping the grass down to $2.54 \mathrm{~cm}$ (1 
inch) and placing the clippings in a convective oven at $60^{\circ} \mathrm{C}$ until they are completely dry. Before seeding the pots, each treatment was tested for stability using curly cress seed germination procedures according to USCC (1997).

\section{Pot Study Results}

Table 3 summarizes the results. The germination index was highest for the mulch and food waste treatments and tended to be lower for the poultry litter composts. Only PLC2 had a germination index that could indicate possible toxicity $(38.1 \%)$, but this treatment also exhibited the highest respiration rate, ammonia concentration $(357 \mathrm{ppm})$ and total salts content $(7.13$ mmhos).

Table 3 Results from pot study on vegetation establishment.

\begin{tabular}{cccccc}
\hline Treatment & $\begin{array}{c}\text { Germination } \\
\text { Index }\end{array}$ & $\begin{array}{c}\text { Two month } \\
\text { \%cover }\end{array}$ & $\begin{array}{c}\text { Two month } \\
\text { Biomass }(\mathrm{g})\end{array}$ & $\begin{array}{c}\text { Six month } \\
\text { \%cover }\end{array}$ & $\begin{array}{c}\text { Six month } \\
\text { Biomass (g) }\end{array}$ \\
\hline PLC1 & 57 & 69 & 44.2 & 90 & 56.3 \\
PLC2 & 38 & 42 & 20.9 & 79 & 33.1 \\
PLC3 & 59 & 92 & 31.6 & 84 & 32.7 \\
MSC & 53 & 73 & 29.1 & 83 & 33.6 \\
BSC & 66 & 93 & 27.9 & 78 & 18.9 \\
FWC & 82 & 81 & 22.8 & 83 & 30.4 \\
YWC & 50 & 58 & 1.3 & 80 & 19.5 \\
WMf & 67 & 38 & 2.2 & 42 & 1.2 \\
WMm & 94 & 42 & 31.0 & 86 & 0.9 \\
WMm\&PLC2 & 59 & 77 & 29.8 & 78 & 33.3 \\
WMm\&MSC & 91 & 100 & 79.9 & 99 & 26.8 \\
Hydroseed & & & & 67.0 \\
\hline
\end{tabular}

The hydroseeded pots grew the most biomass and cover. This was, in part, due to experimental error in that it was the only treatment that had two grass seed species (warm and cool season) and also may have received more seed than the other treatments. The poultry litter composts and the biosolids compost had the highest initial cover and growth. These treatments tended to have lower $\mathrm{C}: \mathrm{N}$ ratios, more available $\mathrm{N}$, and a structure appropriate for supporting vegetation. The two treatments that contained only mulch had much lower initial growth and could not sustain vegetation. Another interesting result was that all of the compost treatments increased in biomass from two to six months except for the biosolids compost. Since composts supply both macro and micronutrients to support vegetation, they offer advantages over the mulch treatments that were exhibiting symptoms of nitrogen deficiency (yellowing of leaves). This study demonstrated that stable and nutrient rich compost products can be excellent media for grass establishment. Although performance of individual media varied, the biomass production was deemed satisfactory in all media except the mulch pots.

\section{Part 3 Field Plots}

The final part of this study used results from the first two phases to select promising mixes of treatments and compare them to traditional practices at the field scale. In addition, the use of compost filter berms is also being evaluated. A compost filter berm is simply a $0.3-0.5 \mathrm{~m}$ pile of compost or mulch material placed at the bottom of the slope. It is intended to allow water to pool behind it causing sediment to drop out and filter water through the porous structure of the matrix. This study is on-going and will assess these practices over a two year period to also assess long term changes in soil and vegetation.

\section{Materials and Methods}

Seven treatments consisting of a biosolids compost blanket and filter berm (BSCb), a mixture of poultry litter compost blanket and wood mulch filter berm (PLCb), a yard waste compost blanket and filter berm (YWCb), a municipal solid waste compost blanket and mulch filter berm MSCb, a hydroseeded plot with a silt fence (HSsf), a hydroseeded plot with a mulch filter berm (HSb), and a bare soil (Soil) were established near Athens, Georgia. A 10\% slope was established on a 
on a graded Cecil clay loam soil. Each compost and compost mulch blanket was applied at 3.8 $\mathrm{cm}$ depths and filter berms were constructed to be $0.6 \mathrm{~m}$ wide by $0.3 \mathrm{~m}$ high. The test plots were $1 \mathrm{~m}$ wide by $5 \mathrm{~m}$ long. Each treatment was replicated three times for a total of 21 plots.

Landscape borders were used to prevent cross-contamination of runoff from outside the test plot. A portable flume was installed at the base of the slope to channel the runoff into manually held 1-liter sample bottles.

All plots were seeded with Bermuda grass according to Georgia D.O.T specifications. Water quality was measured for a design 25 year, one hour storm (approximately $10 \mathrm{~cm} / \mathrm{hr}$ ) using the rainfall simulator described above for three events; immediately following establishment, at vegetation establishment ( 3 months), and one year after establishment (not completed yet). For each event, water quality samples were taken every five minutes for one hour starting from the beginning of the runoff event to calculate runoff quantity and solids content. A flow weighted sub-sample was also taken at each interval and aggregated for nutrient and chemical analysis. Water quality parameters monitored include Total $\mathrm{P}$, Ortho- $\mathrm{P}$, Total $\mathrm{N}, \mathrm{NO}_{3}-\mathrm{N}, \mathrm{NH}_{4}-\mathrm{N}$, total suspended solids, total solids, dissolved organic carbon. The vegetative growth is being evaluated for percent cover and biomass of the vegetation over time. Soil tests will be performed to evaluate the long-term effects of compost blankets on soil quality and characteristics.

\section{Preliminary Field Test Results}

All of the methods tested reduced solids loss by at least an order of magnitude (Table 4). Initially, there appears to be little difference in the runoff generated by the various treatments but the compost treated plots did retain more solids. The filter berms appeared to be effective; however, there was little difference in solids loss on hydroseeded plots when compared to silt fencing. Initially, nutrient levels in the runoff were quite high on the hydroseeded plots and total nitrogen was particularly high on the biosolids compost treated plot. While results from the pan study seemed to indicate that nutrient levels on these treatments may be excessive, when compared to conventional treatments, the use of compost blankets may offer reductions in nutrient runoff.

Table 4 Preliminary results from field plots

\begin{tabular}{|c|c|c|c|c|c|c|c|}
\hline Treatment & $\begin{array}{c}\text { Initial run } \\
\text { Runoff }(\mathrm{L})\end{array}$ & $\begin{array}{c}\text { Initial run } \\
\text { Soil Loss } \\
(\mathrm{g})\end{array}$ & $\begin{array}{c}\text { Initial run } \\
\text { Total N } \\
(\mathrm{mg} / \mathrm{L})\end{array}$ & $\begin{array}{c}\text { Initial run } \\
\text { Total P } \\
(\mathrm{mg} / \mathrm{L})\end{array}$ & $\begin{array}{c}3 \text { months } \\
\text { Runoff }(\mathrm{L})\end{array}$ & $\begin{array}{c}3 \text { Soil Loss } \\
(\mathrm{g})\end{array}$ & $\begin{array}{c}\text { 2months } \\
\text { cover }(\%)\end{array}$ \\
\hline Soil & 189 & 28650 & 1.83 & 0.01 & 205 & 25147 & 17 \\
\hline BSCb & 170 & 471 & 71.60 & 4.12 & 43 & 84 & 57 \\
\hline PLCb & 143 & 708 & 9.74 & 3.07 & 22 & 65 & 64 \\
\hline YWCb & 147 & 395 & 14.42 & 2.15 & 36 & 61 & 62 \\
\hline HSb & 133 & 1372 & 14.38 & 19.39 & 144 & 979 & 22 \\
\hline HSsf & 164 & 1182 & 40.11 & 25.87 & 90 & 348 & 22 \\
\hline MSCb & 101 & 855 & 0.04 & 2.05 & 8 & 27 & 59 \\
\hline
\end{tabular}

Runoff amounts for the three month run were much lower. The plots received less than $4 \mathrm{~cm}$ of natural rainfall between these runs and were very dry prior to the simulation. The plots that had compost blankets produced much less runoff and soil loss than the control or the hydroseeded plots. Due to the dry conditions vegetation establishment was not great on any of the treatments but the compost blankets had more cover than the hydroseeded treatments. On the hydroseeded plots, much of the grass seed was transported from the top of the plots and deposited at the silt fence or berm resulting in dense vegetation at the end of the plot. Soil quality and weed growth parameters are currently being evaluated.

\section{CONCLUSIONS}

Overall, this series of studies is investigating the use of compost and mulch materials for stabilization of disturbed slopes. The first phase of the study looked primarily at the impacts of surface blankets of twelve different compost and mulch materials on total solids loss and water quality and found that mulches generally produced runoff with the lowest solids and nutrient 
contents. Compost blankets were much less erodible than bare soil and compost maturity seemed to be an important factor as respiration rate was significantly correlated to solids loss and raw poultry litter produced more runoff and erosion than bare soil and three different poultry litter composts. Effective erosion control strategies must both protect the soil surface and establish and sustain vegetation and the second part of this project looked at the impacts of these same materials on grass establishment and growth. The findings indicated that the compost treatments were much more effective than the mulch treatments at establishing and maintaining grass under these conditions. The final phase of this study compared four combinations of compost blankets and berms to both bare soil and conventional treatments such as hydroseeding and silt fences. Preliminary results indicate that the use of compost blankets and berms offer significant improvements in water quality through improved erosion control and reduction in nutrient loads as well as improving the establishment of vegetation. These results are for moderate slopes $(10 \%)$ with little concentrated flow so further work is needed to determine the range of conditions to which these results would apply. Further analysis is on-going to document the long term changes in soil quality and vegetation using these treatments.

\section{Acknowledgements}

The authors would like to acknowledge the U.S. Poultry and Egg Association and the National Animal and Poultry Waste Management Center for their financial support and all the compost producers that supplied materials and other resources for use in this study.

\section{REFERENCES}

1. Adams, J.E. 1966. Influence of mulches on runoff, erosion, and soil moisture depletion. Soil Sci Soc Amer Proc 30:110-114.

2. Agassi, M., A. Hadas, Y. Benyamini, G.J. Levy, L. Kautsky, L. Avrahamov, and H. Zhevelev. 1998. Mulching effects of Composted MSW on Water Percolation and Compost Degradation Rate. Compost Science and Utilization 6(3):34-41.

3. Demars, K., R. Long and J. Ives. 2000. Use of wood waste materials for erosion control. Technical Report prepared for The New England Transportation Consortium, April, 2000. NETCR 20. Project \# 97-3, The University of Connecticut, Storrs, CT.

4. Ermine, D.C., and F.K. Ligon. 1988. Effects of discharge fluctuation and the addition of fine sediment on stream fish and macroinvertebrates below a water filtration facility. Environmental Management 12(1):85-97.

5. Foster, G.R., R.A. Young, M.J.M. Romkens, and C.A. Onstad. 1985. Processes of Soil Erosion by Water. In: Follet, R.F. and B.A. Stewart (eds.). Soil Erosion and Crop Productivity. ASA, CSSA and SSSA, Madison, WI. Pp.137-162.

6. Glanville, T.D., R.A. Perrsyn and T.L. Richard. 2001. Impacts of Compost Application on Highway Construction Sites. ASAE Meeting Paper No. 01-012076. St. Joseph, MI: ASAE.

7. Giddens, J. and A.P. Barnett. 1980. Soil loss and microbiological quality of runoff from land treated with poultry litter. J. Environ. Qual. 9(3):518-520.

8. Gilley, J.E. and L.M. Risse. 2001. Runoff and Soil Loss as Affected by the Application of Manure. Trans ASAE 43(6):

9. Kramer, L.A. and L.D. Meyer. 1969. Small amounts of surface mulch reduce soil erosion and runoff velocity. Trans ASAE 12:638-641.

10. Laflen, J.M., J.L. Baker, R.O. Hartwig, W.A. Buchele, and H.P. Johnson. 1978. Soil and Water Losses from Conservation Tillage Systems. Trans. ASAE 21:881-885.

11. Meyer, L.D., C.B. Johnson, and G.R. Foster. 1972. Stone and Wood Chip Mulches for Erosion Control on Construction Sites. J. Soil Water Conserv., 27:264-269. 
12. Michaud, M. 1995. Recycled materials used as erosion control mulches. In: Compost Utilization in Horticultural Cropping Systems, eds. P.J. Stoffella and B.A. Kahn, Lewis Publishers.

13. Mitchell, D. 1997. Compost Utilization by Departments of Transportation in the United States. Florida Department of Transportation Report. Tallahassee, Florida.

14. Risse, L. M., L. B. Faucett, M. A. Nearing, J. W. Gaskin, and L. T. West. 2002. Runoff, erosion, and nutrient losses from compost and mulch blankets under simulated rainfall. Proceedings of the 2002 International Symposium Composting and Compost Utilization, May 6-8, Columbus, OH. M. R. Fredrick, R. F. Runk, and H. A. . Hoitink (ed.).

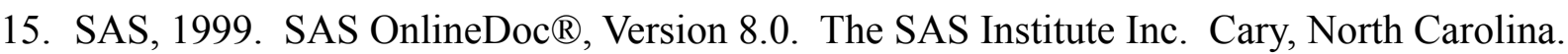

16. Storey, B.B., J.A. McFalls, and S.H. Godfrey. 1996. The use of compost and shredded brush on Rights-of -Way for Erosion Control: Final Report No. 1352-2F. Texas Transportation Institute. Austin, Texas.

17. USCC, 1997. Test Methods for the Examination of Composting and Compost. First Edition. The United States Composting Council, Amherst, Ohio.

18. USEPA, 1997. Innovative uses of compost - Erosion Control, Turf Remediation, and Landscaping. EPA530-F-97-043. United States Environmental Protection Agency, Washington, DC.

19. Vleeschauwer, D.D., R. Lal, and M.D. Boodt. 1978. The comparative effects of surface applications of organic mulch versus chemical soil conditioners on physical and chemical properties of the soil and on plant growth. Catena 5:337-349.

20. Westerman, P.W., T.L. Donnelly, and M.R. Overcash. 1983. Erosion of Soil and Poultry Manure- A Laboratory Study. Trans ASAE 26(5):1070-1078. 